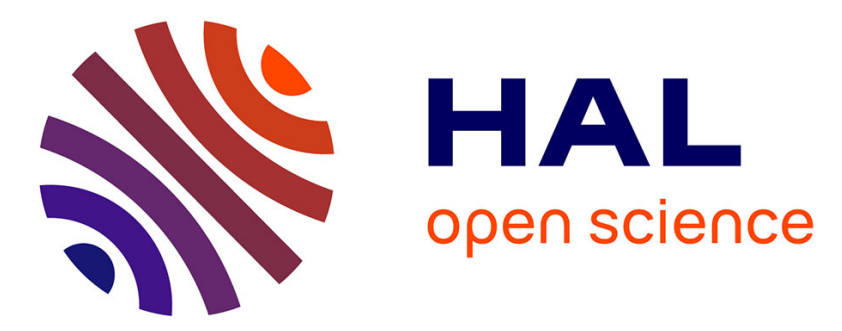

\title{
Powered two-wheeler drivers' risk of hitting a pedestrian in towns
}

\author{
Nicolas Clabaux, Jean-Yves Fournier, Jean Emmanuel Michel
}

\section{To cite this version:}

Nicolas Clabaux, Jean-Yves Fournier, Jean Emmanuel Michel. Powered two-wheeler drivers' risk of hitting a pedestrian in towns. Journal of Safety Research, 2014, 51, pp.1-5. hal-01062170

\section{HAL Id: hal-01062170 https://hal.science/hal-01062170}

Submitted on 9 Sep 2014

HAL is a multi-disciplinary open access archive for the deposit and dissemination of scientific research documents, whether they are published or not. The documents may come from teaching and research institutions in France or abroad, or from public or private research centers.
L'archive ouverte pluridisciplinaire HAL, est destinée au dépôt et à la diffusion de documents scientifiques de niveau recherche, publiés ou non, émanant des établissements d'enseignement et de recherche français ou étrangers, des laboratoires publics ou privés. 
Paper published in the Journal of Safety Research

Reference: N. Clabaux, J.Y. Fournier, J.E. Michel (2014), Powered two-wheeler drivers' risk of hitting a pedestrian in towns. Journal of Safety Research 51, pp.1-5

2014 National Safety Council and Elsevier Ltd.

http://dx.doi.org/10.1016/j.jsr.2014.07.002

\title{
Powered two-wheeler drivers' risk of hitting a pedestrian in towns
}

\author{
Nicolas Clabaux, Jean-Yves Fournier, Jean-Emmanuel Michel \\ IFSTTAR, French Institute of Science and Technology for Transport, Development and Networks, Laboratory of \\ Accident Mechanism Analysis, 304 chemin de la Croix Blanche, \\ F-13300 Salon de Provence, France
}

\section{Keywords:}

Powered two-wheelers

Motorcycle

Moped

Pedestrian

Crash risk

\section{Highlights}

In this study, powered two-wheeler drivers' risk of hitting a pedestrian in towns and fourwheeled vehicle drivers' risk are compared. Per kilometer driven, powered two-wheeler drivers run a risk of hitting and injuring a pedestrian that is nearly three times higher than for four-wheeled vehicle drivers. Among the different categories of powered two-wheelers, moped drivers run the highest risk.

\begin{abstract}
Introduction: The risk of collision between pedestrians and powered two-wheelers is poorly understood today. Other than the study by Paulozzi (2005) which showed that, per kilometer covered in towns, the risk for powered two-wheeler drivers to fatally injure a pedestrian is 2.02 times $(95 \%$ CI: $1.23 ; 3.30)$ greater than the risk for automobile drivers, no other scientific studies have dealt with this question as far as we know. The objective of this research is to determine the risk for powered two-wheeler drivers of hitting and injuring a pedestrian per kilometer driven in towns and to compare this risk with that run by fourwheeled vehicle drivers.

Method: Using the bodily injury accidents recorded by the police on nine roads in the city of Marseille in 2011 and a campaign of observations of powered two-wheeler traffic, we estimated the risk per kilometer driven by powered two-wheeler drivers of hitting a pedestrian and compared it with the risk run by four-wheeled vehicle drivers.

Results: The results show that the risk for powered two-wheeler drivers of hitting and injuring a pedestrian is significantly higher than the risk run by four-wheeled vehicle drivers. On the nine roads studied, it is on average 3.33 times higher $(95 \% \mathrm{CI}: 1.63 ; 6.78)$. Taking four more years into account made it possible to consolidate these results and to tighten the confidence interval.

Conclusion: There does indeed seem to be problems in the interactions between pedestrians and powered two-wheeler users in urban traffic. These interaction problems lead to a higher risk of hitting and injuring a pedestrian for powered two-wheeler drivers than for fourwheeled vehicle drivers. The analysis of the police reports suggests that part of this increased
\end{abstract}


risk comes from filtering maneuvers by powered two-wheelers. Practical Applications effective: Possible countermeasures deal with the urban street layout. Measures consisting in reducing the width and the number of traffic lanes to a strict minimum and installing medians or pedestrian islands, could be an effective way for the prevention of urban accidents between pedestrians and powered two-wheelers.

\section{INTRODUCTION}

For the last fifteen years or so, the use of motorcycles, scooters and mopeds, collectively termed powered two-wheelers, has increased sharply in Europe, notably in large, congested metropolitan areas (European Commission, 2013). In France, the increase in the number of powered two-wheelers ${ }^{1}$ in traffic in major urban areas has been accompanied by a stagnation in automobile use (collective work, 2010). Is this increase in the number of powered twowheelers in traffic good news for pedestrian safety? To find out, one prerequisite would be to understand the risk of accidents between pedestrians and powered two-wheelers. But our understanding is inadequate in this area. Indeed, other than the Paulozzi study (2005) which found that, in the United States, the risk per kilometer driven in towns by powered twowheeler drivers of fatally injuring a pedestrian is 2.02 times (95\% confidence interval: 1.23 ; 3.30) higher than the risk for automobile drivers; no other scientific studies have dealt with this question as far as we know. In France, we know the number of bodily injury accidents between pedestrians and powered two-wheelers recorded by the police each year and the number of pedestrians injured and killed. For the year 2011, 1,636 bodily injury accidents involving a pedestrian and a powered two-wheeler were recorded, or $13.6 \%$ of the pedestrian accidents recorded. Thirty-four pedestrians were killed in these accidents, or $6.6 \%$ of pedestrians killed (ONISR, 2012). If we compare these proportions with the share that powered two-wheelers represent in traffic, which is approximately $2 \%$ according to the French national transport accounts (CGDD, 2012), this suggests that, in France as well, powered two-wheeler users have a greater chance of hitting and injuring a pedestrian than do automobile drivers per kilometer driven. But is this trend verified in large urban areas where powered two-wheelers are significantly more numerous ${ }^{2}$ and where pedestrians no doubt expect to interact with them more? And if this is confirmed overall for all powered twowheelers, does it also hold true for each category of powered two-wheelers (mopeds, light motorcycles and heavy motorcycles). The study reported on in this paper aimed at answering these questions. More precisely, the main hypothesis that we are seeking to validate or invalidate is that of an increased risk among powered two-wheeler drivers of hitting and injuring a pedestrian in the center of large urban areas compared with automobile drivers.

\section{DATA AND METHOD}

The study carried out concerns nine roads located in the center of Marseille. With more than 1.5 million inhabitants, Marseille is the second largest urban area in France after Paris in terms of the number of inhabitants. Located in the south of the country on the Mediterranean

\footnotetext{
${ }^{1}$ In France, powered two-wheelers are separated into three main administrative categories: $(i)$ mopeds, with engines under $50 \mathrm{~cm}^{3}$ and whose construction limits their speed to $45 \mathrm{~km} / \mathrm{h}$. They can be driven from the age of 14. In this category; scooters are the majority although traditional pedal mopeds and a few trail and sport mopeds with gearboxes can be found in traffic as well; (ii) light motorcycles, with engines greater than $50 \mathrm{~cm}^{3}$ and less than $125 \mathrm{~cm}^{3}$. They can be driven with an automobile driver's license under certain conditions. Here again, scooters account for a very large share of these. There are, however, different basic, trail and sport models on the market (iii) heavy motorcycles, with engines greater than $125 \mathrm{~cm}^{3}$, which require a motorcycle license. This category includes the following seven types: basic, roadster, touring, sport, trail, custom and scooter.

${ }^{2}$ For example, in the center of Paris and Marseille, powered two-wheelers account for approximately $17 \%$ of traffic according to Maestracci, Prochasson, Geffroy and Pecoud (2012), Kopp (2011) and Michel, Fournier and Clabaux (2013).
} 
coast, it has a long history of high powered two-wheeler use. For the most part, the roads studied are main roads in the city of Marseille's road network. They have a certain number of features in common such as the presence of several lanes in the same direction, crossroads that generally have traffic lights and the existence of bus lanes in at least one traffic direction.

For each of the nine roads, we have estimated the risk for powered two-wheelers of hitting and injuring a pedestrian in 2011. To do this, we compared the number of powered twowheelers that hit and injured a pedestrian to the number of powered twowheelers $x$ kilometers exposed to this risk (number of powered two-wheelers that drove on the road in 2011 multiplied by the length of the road). The same approach was adopted for drivers of four-wheeled vehicles in order to estimate their risk of hitting and injuring a pedestrian per kilometer driven. Four-wheeled vehicles include passenger cars, light-duty trucks and heavy trucks ${ }^{3}$. We then expressed the relationship between these rates in the form of a relative risk to obtain an estimation of the increased risk or reduced risk for powered twowheelers of hitting and injuring a pedestrian compared with four-wheeled vehicles. Lastly, an overall relative risk and its $95 \%$ confidence interval were calculated for all the roads by undertaking a meta-analysis. For this, we based our work on the method described in Elvik and Vaa (2004). We should point out that the investigations covered weekdays (Mondays to Saturdays, excluding public holidays) during daytime hours (from 6.00 am to $10.00 \mathrm{pm}$ ).

The accident data we used came from the reports drawn up by the police in 2011 concerning bodily injury accidents ${ }^{4}$. The data on road traffic were transmitted to us by the direction Marseille Provence Métropole's Direction Gestion des Equipements de Trafic (Traffic Equipment Management Division). This service centralizes the traffic data gathered by the inductive loop traffic counters set up on the road network in the city of Marseille. As powered two-wheelers are not distinguished from four-wheeled vehicles in these counts, we undertook a campaign of powered two-wheeler traffic observation in order to estimate the share that they represent in overall traffic. Fifty-two hours of observations were carried out on the nine roads with random distribution throughout the entire year of 2011. Each sequence of observations lasted one hour and was carried out by a team of two investigators positioned on the sidewalk. These observations showed that, on the nine roads, powered two-wheelers on average account for $16.3 \%$ of the road traffic. Mopeds (with engines under $50 \mathrm{~cm}^{3}$ ), light motorcycles (with engines under $125 \mathrm{~cm}^{3}$ ) and heavy motorcycles (engines greater than $125 \mathrm{~cm}^{3}$ ) represent $20 \%$, $48 \%$ and $32 \%$ of this traffic, respectively (for further details on the observation method and the results, see the bibliographical reference for Michel, Fournier and Clabaux (2013).

We have access to the hourly road traffic on each of these roads for the years 2007, 2008, 2009 and 2010, as well as the precise locations of the pedestrian accidents; the same approach was adopted, this time cumulating the years 2007, 2008, 2009, 2010 and 2011. We should point out that these additional investigations were based on the hypothesis that the share of powered two-wheelers in traffic did not change between the 2007-2010 period and 2011, since we did not carry out observations of powered two-wheeler traffic in 2007, 2008, 2009 and 2010. This hypothesis appears acceptable to us ${ }^{5}$. Taking these additional four years into

\footnotetext{
${ }^{3}$ We should point out, however, that in the city centre of Marseille, light-duty trucks (motor vehicle having a gross vehicle weight of up to $3.500 \mathrm{~kg}$ ) and heavy trucks (motor vehicle having a gross vehicle weight exceeding $3.500 \mathrm{~kg}$ ) are very much in the minority compared with passenger cars.

${ }^{4}$ In France, a bodily injury traffic accident is defined as an accident involving at least one vehicle that takes place on a road open to traffic and leads to at least one victim (ONISR, 2012).

${ }^{5}$ We feel that this hypothesis is acceptable insofar as, according to the Commissariat Général au Développement Durable (CGDD, 2012), the average annual growth rate for powered two-wheelers in road traffic for the 20072011 period was $2.1 \%$ (see CGDD, 2012, p.61). Indeed, this share grew the most up to the year 2007 (ibid.).
} 
account should enable us to consolidate the results obtained for the year 2011. It should also enable us to detect a trend for the various categories of powered two-wheelers.

\section{RESULTS}

In 2011, on the nine roads studied, 11 powered two-wheelers and 19 four-wheeled vehicles (including 17 automobiles) hit and injured a pedestrian. Table 1 presents the number of vehicles that hit and injured a pedestrian for each road, the annual exposure of two-wheelers and four-wheeled vehicles on each road (expressed in vehicles x kilometers), the estimated relative risk and the $95 \%$ confidence interval.

The meta-analysis of the results obtained individually on each road gives an overall relative rate of 3.33 with a $95 \%$ confidence interval of $[1.63 ; 6.78]$. The test of heterogeneity performed $^{6}$ does not make it possible to conclude that the results are heterogeneous for the different roads, since $\mathrm{Q}=3.61$ and $\mathrm{p}=0.89$.

According to these results, on the nine roads studied in 2011, powered two-wheeler drivers had a risk of hitting and injuring a pedestrian that, on average, was 3.33 times greater than for four-wheeled vehicle drivers.

This result nonetheless remains fragile given the small number of accidents recorded on each road (see Table 1). Taking four additional years into account should enable us to specify this increased risk and to tighten the confidence interval. Table 2 presents the number of vehicles that hit and injured a pedestrian on each road during the 2007-2011 period, the exposure of two-wheelers and four-wheeled vehicles during those five years, the estimated relative risk and the $95 \%$ confidence interval.

It appears that powered two-wheelers' risk of hitting a pedestrian is greater than that of fourwheeled vehicles on the nine roads studied (see Table 2). The lower bound of the confidence interval is greater than 1 on five of the nine roads. The results of the meta-analysis give an average relative risk of 3.06 with a tighter $95 \%$ confidence interval between 2.26 and 4.14 . Here again, the test of heterogeneity does not make it possible to conclude that the results are heterogeneous between the roads $(\mathrm{Q}=2.63 ; \mathrm{p}=0.96)$.

TABLE 1 Number of powered two-wheelers and powered four-wheelers having hit and injured a pedestrian on each road in 2011, number of kilometers driven by two-wheelers and four-wheeled vehicles on each road in 2011, estimated relative risks and $95 \%$ confidence interval

\begin{tabular}{|c|c|c|c|c|c|c|c|}
\hline Roads & $\begin{array}{c}\mathrm{VKT}^{*} \text { of } \\
\text { powered two- } \\
\text { wheelers }\end{array}$ & $\begin{array}{l}\text { VKT of powered } \\
\text { four-wheelers }\end{array}$ & $\begin{array}{c}\text { Number of } \\
\text { powered two- } \\
\text { wheelers } \\
\text { hitting and } \\
\text { injuring a } \\
\text { pedestrian }\end{array}$ & $\begin{array}{l}\text { Number of } \\
\text { powered four } \\
\text {-wheelers } \\
\text { hitting and } \\
\text { injuring a } \\
\text { pedestrian }\end{array}$ & $\begin{array}{l}\text { Relative } \\
\text { risk }\end{array}$ & \multicolumn{2}{|c|}{$\begin{array}{l}95 \% \text { confidence } \\
\text { interval }\end{array}$} \\
\hline Baille Blvd & 1524143 & 7728124 & 1 & 0 & 15.21 & 0.62 & 373.4 \\
\hline Corderie Blvd & 397401 & 2014302 & 0 & 0 & 5.07 & 0.10 & 255.4 \\
\hline F. Duparc Bvld & 1892313 & 9638033 & 2 & 3 & 3.40 & 0.57 & 20.32 \\
\hline Mazargues Ave & 579353 & 2933874 & 0 & 1 & 1.69 & 0.07 & 41.44 \\
\hline Michelet Bvld & 3534359 & 17837188 & 0 & 3 & 0.72 & 0.04 & 13.96 \\
\hline Prado 1 Ave & 1950733 & 9877126 & 4 & 8 & 2.53 & 0.76 & 8.41 \\
\hline Prado 2 Ave & 1516459 & 7679216 & 1 & 0 & 15.19 & 0.62 & 372.9 \\
\hline Rome St & 473034 & 2400185 & 3 & 3 & 5.07 & 1.02 & 25.14 \\
\hline Schloesing Bvld & 2084719 & 10568511 & 0 & 1 & 1.69 & 0.07 & 41.48 \\
\hline
\end{tabular}

*Vehicle kilometers of travel

\footnotetext{
${ }^{6}$ The test of heterogeneity carried out was that described in DerSimonian and Laird (1986).
} 
TABLE 2 Number of powered two-wheelers and powered four-wheelers having hit and injured a pedestrian on each road during the 2007-2011 period, number of kilometers driven by two-wheelers and four-wheeled vehicles during the period, estimated relative risks and $95 \%$ confidence interval

\begin{tabular}{|c|c|c|c|c|c|c|c|}
\hline Roads & $\begin{array}{c}\text { VKT of } \\
\text { powered two- } \\
\text { wheelers* }\end{array}$ & $\begin{array}{l}\text { VKT of powered } \\
\text { four-wheelers }\end{array}$ & $\begin{array}{c}\text { Number of } \\
\text { powered two- } \\
\text { wheelers } \\
\text { hitting and } \\
\text { injuring a } \\
\text { pedestrian }\end{array}$ & $\begin{array}{c}\text { Number of } \\
\text { powered } \\
\text { four-wheelers } \\
\text { hitting and } \\
\text { injuring a } \\
\text { pedestrian }\end{array}$ & $\begin{array}{l}\text { Relative } \\
\text { risk }\end{array}$ & \multicolumn{2}{|c|}{$\begin{array}{c}95 \% \text { confidence } \\
\text { interval }\end{array}$} \\
\hline Baille Bvld & 7341245 & 37223557 & 11 & 19 & 2.94 & 1.40 & 6.17 \\
\hline Corderie Bvld & 1955336 & 9910945 & 1 & 5 & 1.01 & 0.12 & 8.68 \\
\hline F. Duparc Bvld & 9609473 & 48918159 & 7 & 15 & 2.38 & 0.97 & 5.83 \\
\hline Mazargues Ave & 2857838 & 14472221 & 3 & 7 & 2.17 & 0.56 & 8.39 \\
\hline Michelet Bvld & 17829166 & 89925923 & 9 & 15 & 3.03 & 1.32 & 6.92 \\
\hline Prado 1 Ave & 10155350 & 51417160 & 19 & 31 & 3.10 & 1.75 & 5.49 \\
\hline Prado 2 Ave & 7392987 & 37439148 & 8 & 9 & 4.50 & 1.74 & 11.67 \\
\hline Rome St & 2360430 & 11976851 & 8 & 11 & 3.69 & 1.48 & 9.17 \\
\hline Schloesing Bvld & 9666643 & 49005159 & 2 & 2 & 5.07 & 0.71 & 35.99 \\
\hline
\end{tabular}

*Vehicle kilometers of travel

According to these results, powered two-wheeler users have, on average, three times the risk (3.06 times more) of hitting and injuring a pedestrian per kilometer driven than four-wheeled vehicle drivers. This result is statistically significant at a 0.05 threshold. The initial hypothesis is validated. When four-wheeled vehicles are limited to passenger cars, the relative risk is similar: powered two-wheeler users have 3.12 times (95\% CI [2.29 ; 4.24]) more of a risk of hitting and injuring a pedestrian than passenger car drivers. It was not possible to make any comparison with the risk of light-duty truck and heavy truck drivers due to the extremely small number of light-duty trucks and heavy trucks having hit a pedestrian during the period studied.

Among the different categories of powered two-wheelers, mopeds users are those with the highest risk, as it is 6,04 times higher $(95 \%$ IC $[3.88 ; 9.41]$ ) than for automobile drivers (see Table 3). Light motorcycle drivers have a lower risk, as on average for the nine roads it is 2.73 time greater than for automobile drivers $(95 \%$ IC $[1.75 ; 4.26]$. The risk for heavy motorcycle users is slightly higher: 2.91 with a $95 \%$ confidence interval of $[1.80 ; 4.72]$. We should point out that the tests of heterogeneity carried out made it possible to conclude that there is no heterogeneity in the results between the roads for the three categories of powered two-wheelers. Thus, the risk for mopeds users is 2.06 time greater than for light motorcycle users $(95 \%$ IC $[1.10 ; 3.86]$ and 1.86 time greater than for heavy motorcycle users $(95 \%$ IC $[1.00 ; 3.43]$. No significant difference was observed between light motorcycle drivers and heavy motorcycle drivers.

TABLE 3 Risk of drivers in the different categories of powered two-wheelers of hitting and injuring a pedestrian compared with automobile drivers (years 2007 to 2011)

\begin{tabular}{lccc}
\hline Powered two-wheeler categories & Relative mean risk on the 9 streets & 95\% confidence interval \\
\hline Mopeds $\left(<50 \mathrm{~cm}^{3}\right)$ & 6.04 & 3.88 & 9.41 \\
Light motorcycles $\left(<125 \mathrm{~cm}^{3}\right)$ & 2.73 & 1.75 & 4.26 \\
Heavy motorcycles $\left(>125 \mathrm{~cm}^{3}\right)$ & 2.91 & 1.80 & 4.72 \\
\hline
\end{tabular}

\section{DISCUSSION AND CONCLUSION}

Although they would need to be consolidated by taking into account a larger number and a wider variety of roads, the results presented here show that powered two-wheeler users in the city center of Marseille run a risk of hitting and injuring a pedestrian that is nearly three times 
greater (3.06 times greater) than for four-wheeled vehicle drivers. These results are consistent with those found by Paulozzi (2005), who showed that, in the United States, powered twowheeler drivers have a risk of fatally injuring a pedestrian per kilometer driven in towns that is 2.02 times greater than for car drivers. The exposure data that we use here are much more precise, however, as they are based on a campaign of observations of powered two-wheeler traffic on the same roads as those for which the accident data were gathered. Paulozzi (2005) used information on vehicle miles traveled by motorcycles from the highway statistics of the US Department of Transportation's Federal Highway Administration. Furthermore, the number of accidents involving powered two-wheelers was not enough to estimate the risk of collision for each powered two-wheeler category. The risk obtained is thus an average risk for all powered two-wheeler categories taken together: mopeds, scooters, off-road motorcycles and other two and three-wheeled motorized vehicles (Paulozzi, 2005, page 232).

Concerning the reasons for the increased risk, the in-depth analysis of three years (years 2006, 2007 and 2008) of accident reports drawn up by the police on the nine roads studied ${ }^{7}$ for accidents involving a pedestrian and a powered two-wheeler during weekdays and daytime hours -36 cases $^{8}$ - suggests that part of this increased risk could be related to the atypical character of certain powered two-wheeler trajectories. This notably includes filtering forward by using the left-hand edge of the carriageway ( 8 cases out of 36) and filtering forward between cars - lane splitting ( 2 cases out of 36 ). These trajectories, which are specific to powered two-wheelers and are forbidden in France, could make them harder to see because they are hidden by the vehicles they are overtaking and are unpredictable because they thwart the common information-gathering strategies adopted by pedestrians. It should be pointed out that other cases involve trajectories that are not unique to powered two-wheelers, but which they adopt more often than four-wheeled vehicles. This concerns filtering forward by driving in a free traffic lane directly adjacent to the lane of stopped vehicles, whether to the right or to the left of the stopped lane ( 7 cases out of 36) or driving in a bus lane ${ }^{9}-7$ cases out of 36 , including 4 cases of filtering forward. In the end, 21 cases out of 36 involved a powered twowheeler that was filtering forward at the time of the accident. In four other cases, it is probable but not certain. In terms of prevention, this suggests that any measure that could reduce filtering by powered two-wheelers, could have the effect of reducing the increased risk of collision between powered two-wheelers and pedestrians. One possible strategy deals with the urban street layout. A study of accident sites suggests that measures consisting in reducing the width and number of traffic lanes to a strict minimum and installing medians or pedestrian islands between the lanes traveling in opposite directions probably could have the effect of reducing fast filtering forward and lane splitting maneuvers by powered two-wheelers due to the reduced space available for performing them. These layouts have positive effects on the risk of pedestrian injuries for all types of vehicles taken together (Elvik and Vaa, 2004). As far as we know, however, there are no assessment studies that show the beneficial effects on the increased risk specific to collisions between pedestrians and powered two wheelers.

Concerning the even greater increased risk among moped users of hitting a pedestrian compared with the other categories of powered two-wheelers, it is probable that this increased risk comes at least in part from the various risk factors already well identified in the scientific literature, such as young age (Kopjar, 1999; Aare and Holst, 2003; Lardelli-Claret et al., 2005;

\footnotetext{
${ }^{7}$ These analyses were carried out as part of a different study.

${ }^{8}$ During the years 2006, 2007 and 2008, 44 accident reports were drawn up by the police on the nine roads studied. 8 cases were judged as being non-analyzable (police report containing too little information to arrive at a real understanding of the case).

${ }^{9}$ In a previous study (Michel, Fournier and Clabaux, 2013), we demonstrated that, although they are not legally allowed to do so, powered two-wheelers are the users that drive in bus lanes the most. They account for $41 \%$ of the traffic driving in these lanes, far ahead of buses, which account for $12 \%$ of this traffic.
} 
Moskal, Martin and Laumon, 2012), inexperience (Yannis, Golias and Papadimitriou, 2005; SWOV, 2006; Blackman and Haworth, 2013), a greater tendency to intentionally break certain traffic rules (Van Elslande and Marechal, 2008; Steg and Van Brussel, 2009; Wang et al., 2012) and, more generally, to take risks (ECMT, 2000; Yannis, Golias and Papadimitriou, 2005; Brandau et al., 2011). For example, based on 94 in-depth inquiries into accident cases involving young moped drivers, Van Elslande and Marechal (2008) found that intentional violation of a safety rule occurs in nearly one in five cases whereas it is only seen in $5 \%$ of all cases in the general population. Moreover, it's also possible that the higher maneuverability of mopeds in comparison with motorcycles (smaller and lighter vehicles) encourage to perform more frequently risky manoeuvres like weaving through traffic or filtering. Nonetheless, further analyses covering a wider sampling of cases would be needed to confirm the influence of these different aspects in accidents involving pedestrians.

Consistent with the results of Paulozzi (2005), our study thus supports the idea that there appears to be problems in the interactions between pedestrians and powered two-wheeler users, notably in urban areas. There is a risk that these problems will grow in the coming years, not only in developed countries where powered two-wheelers are the subject of renewed interest (Haworth, 2012), but also - and especially - in low and medium-income countries where powered two-wheelers already account for a large share of the vehicles on the road (respectively $30 \%$ and $46 \%$ of road motor vehicles according to Nishitateno and Burke, 2014) and where access to vehicle ownership is notably achieved through powered twowheelers. In these countries, pedestrians and powered two-wheeler users already account for nearly half of all victims (WHO, 2009). This situation gives rise to an urgent need for research in this field to gain a better understanding of the reasons for this increased risk and thus to be able to define effective preventive measures.

\section{Acknowledgements}

The authors would like to thank Mr. Marc Jouvenne and Mr. Franck Lavergne of the Marseille Provence Métropole Urban Community's Direction Gestion des Equipements de Trafic (Traffic Equipment Management Division), without whom this study would not have been possible.

\section{REFERENCES}

Aare, M., Holst, H. (2003). Injuries from motorcycle and moped crashes in Sweden from 1987 to 1999. Injury Control and Safety Promotion, 10(3), 131-138.

Blackman, R.A., Haworth, N. (2013). Comparison of moped, scooter and motorcycle crash risk and crash severity. Accident Analysis and Prevention 57, 1-9. http://dx.doi.org/10.1016/j.aap.2013.03.026

Brandau, H., Daghofer, F., Hofmann, M., Spitzer, P. (2011). Personality subtypes of young moped drivers, their relationship to risk-taking behavior and involvement in road crashes in an Austrian sample. Accident Analysis and Prevention, 43(5), 1713-1719. http://dx.doi.org/10.1016/j.aap.2011.03.030

Collective work. (2010). La mobilité des Français. Panorama issu de l'enquête nationale transports et déplacements 2008. La Revue du Service de l'Observation et des Statistiques (SOeS) du Commissariat Général au Développement Durable. 224p.

Commissariat Général au Développement Durable (CGDD) (2012). Les comptes des Transports en 2011. $49^{\text {ème }}$ rapport à la commission des comptes des transports de la nation. Tome 1. 169p. Paris.

DerSimonian, R., Laird, N. (1986). Meta-analysis in clinical trials. Controlled Clinical Trials, 7, 177-188. 
Elvik, R., Vaa, T. (2004). The handbook of road safety measures. Elsevier Science, Amsterdam, The Netherlands, 1078p.

European Conference of Ministers of Transport (ECMT). (2000). Safety in road traffic for vulnerable road users. OECD Publishing, Paris, 112p. http://doi.org/10.1787/9789264181571en

European Commission. (2013). Making roads safer for motorcycles and mopeds. http://ec.europa.eu/transport/road_safety/users/motorcyclists-mopdeds/index_en.htm

Accessed on 1 July 2013.

Haworth, N. (2012). Powered two wheelers in a changing world - Challenges and opportunities. Accident Analysis and Prevention, 44(1), 12-18.

http://dx.doi.org/10.1016/j.aap.2010.10.031

Kopjar, B. (1999). Moped injuries among adolescents: a significant forgotten problem. Accident Analysis and Prevention, 31(5), 473-478. http://dx.doi.org/10.1016/S00014575(98)00085-2

Kopp, P. (2011). The unpredicted rise of motorcycles: a cost benefit analysis. Transport Policy, 18(4), 613-622. http://dx.doi.org/10.1016/j.tranpol.2011.03.002

Lardelli-Claret, P., Jiménez-Moleón, J.J., de Dios Luna-del-Castillo, J., Garcia-Martin, M. (2005). Driver dependent factors and the risk of causing a collision for two wheeled motor vehicles. Injury Prevention, 11, 225-231. http://dx.doi.org/10.1136/ip.2004.006957

Maestracci, M., Prochasson, F., Geffroy, A., Peccoud, F. (2012). Powered two-wheelers road accidents and their risk perception in dense urban areas: case of Paris. Accident Analysis and Prevention, 49, pp.114-123. http://dx.doi.org/10.1016/j.aap.2011.05.006

Michel, J.E., Fournier, J.Y., Clabaux, N. (2013). Place des deux-roues motorisés dans la circulation urbaine : une étude observationnelle. Transport Environnement Circulation, 217, 58-61.

Moskal, A., Martin, J.L., Laumon, B. (2012). Risk factors for injury accidents among moped and motorcycle riders. Accident Analysis and Prevention, 49, 5-11. http://dx.doi.org/10.1016/j.aap.2010.08.021

Nishitateno, S., Burke, P.J. (2014). The motorcycle Kuznets curve. Journal of Transport Geography, 36, 116-123. http://dx.doi.org/10.1016/j.jtrangeo.2014.03.008

Observatoire National Interministériel de Sécurité Routière (ONISR). (2012). La sécurité routière en France. Bilan de l'année 2011. La documentation française, Paris, 689p.

Paulozzi, L.J. (2005). United States pedestrian fatality rates by vehicle type. Injury Prevention, 11, 232-236. http://dx.doi.org/10.1136/ip.2005.008284

Steg, L., Van Brussel, A. (2009). Accidents, aberrant behaviours, and speeding of young moped riders. Transportation Research Part F, 12, 503-511. http://dx.doi.org/10.1016/j.trf.2009.09.001

SWOV (Institute for Road Safety research). (2006). Young moped riders. SWOV Fact sheet. Institute for Road Safety Research, Leidschendam, the Netherlands, 5p.

Van Elslande, P., Marechal, M. (2008). Accidentologie des cyclomoteurs. Rapport de convention INRETS/La prevention routière. Institut National de Recherche sur les Transports et leur Sécurité, Bron, 81p.

Yannis, G., Golias, J., Papadimitriou, E. (2005). Driver age and vehicle engine size effects on fault and severity in young motorcyclists accidents. Accident Analysis and Prevention, 37(2), 327-333. http://dx.doi.org/10.1016/j.aap.2004.10.003

Wang, X., Xu, Y., Tremont, P.J., Yang, D. (2012). Moped rider violation behavior and moped safety at intersections in China. Transportation Research record, 2281, 83-91. http://dx.doi.org/10.3141/2281-11

World Health Organization (WHO). (2009). Global status report on road safety. Time for action. World Health Organization, Geneva, Switzerland, 287p. 
Note: Parts of this study that include preliminary results were presented at the "La ville sous nos pieds: connaissances et pratiques favorables aux mobilités piétonnes" conference, November 20-22, Montreal, Canada. 